\title{
STUDY ON THE RELATIONSHIP BETWEEN INCOME AND DIRECT PAYMENTS OF AGRICULTURAL PRODUCERS
}

\author{
H. Tsvetanov* \\ Dimitar A. Tsenov Academy of Economics, Svishtov, Bulgaria
}

\begin{abstract}
Reducing the budget for the Common Agricultural Policy (CAP) has given rise to a wide public response and debate both in practice and in the scientific community, as well. The purpose of this study is to study the dependence of income on direct payments, thus demonstrating their importance for agricultural producers. The methods used to convey the present study are scientific research methods: comparative analysis method, induction and deduction method, retrospective analysis and others; illustrative methods - tables, figures and others. Regarding the expected results, this article focuses on the study of indicators for measuring dependence of the income of direct payments made by agricultural producers in terms of achieving economic impact on them. To achieve this goal, the following tasks are set: to characterize the parameters for the study of the relationship between income and direct payments to agricultural producers; to analyze the relationship between income and direct payments to producers via the indicators studied; to bring out the results of the indicators studied for analyzing the relationship between income and direct payments to producers.
\end{abstract}

Key words: CAP, agrarian sector, agrarian economy, agrarian policy, agriculture, grain production.

\section{INTRODUCTION}

In May 2018 the European Commission proposed to reduce the multiannual financial framework after 2020 taking into account Great Britain's exit from the European Union. the departure of from the European Union. This reduction also affects the budget of the Common Agricultural Policy (CAP) (1).

EU member states represented in the Agriculture and Fisheries Council, farms' unions and the European Parlament stand against this proposal for reduction of the support. According to them, the reduction of the two pillars will threaten the viability of European farms, farmers' income and their commitment to ensuring that European consumers are provided with healthy, affordable and quality food, and environmental protection and adaptation on Climate Change (2). The above marked is the basis for

\footnotetext{
*Correspondence to: $H$. Tsvetanov, Chemapool Ltd., Svishtov, Bulgaria, 2, "Tsar Osvoboditel" Street, 5250 Svishtov, E-mail: tsvetanov@chemapool.bg, Phone: +35963160750
}

measuring the dependency of agricultural producers on public payments. In this connection, actual information on the current importance of direct payments for farmers' income in the context of the Common Agricultural Policy of the European Union.

From this point of view, attention is directed towards the use of statistical data from several sources, in particular: the General Directorate for Agriculture and Rural Development (DG AGRI), the Farm Accountancy Data System (FADS), the Organization for Economic Cooperation and Development (OECD) and the Eurostat Statistical Office of the European Union (Eurostat).

\section{INDICATORS FOR MEASURING THE RELATIONSHIP BETWEEN INCOME AND DIRECT PAYMENTS FOR FARMER}

Direct payments are a tool of the Common Agricultural Policy of the European Union, which guarantee a minimum level of the income from agricultural activity (11). To measure income dependence on direct 
payments received by farmers, attention is directed to the following indicators:

- Indicator for calculating the ratio of direct payments and general sub-funds to farm income, known as an indicator of the Agriculture Directorate "Agriculture and rural areas' development". It gives a prediction for two variables:

The first variable is determined as a ratio of the direct payments to the factor income from agricultural activities. Information for them is provided based on data on the costs of direct payments for the realization of the General Agricultural Policy, which data is taken from the Financial Statement of the the European Fund for guarantee on the agriculture and the factor income from the economical accounts of Eurostat for agriculture.

Direct payments are made through schemes for support of farmers under the European Agricultural Guidance and Guarantee Fund (EAGGF), the so-called Pillar I of the Common Agricultural Policy of the European Union. They aim to provide priority support to the farmers' income, but they are also expected to contribute to soil preservation, increased bio- logical diversification and mitigation of the effects of climate change. A national budget threshold is set for each Member State (Owen, P \& other, 2018).

$$
\kappa=\frac{\text { direct payments }+\sum \text { common subsudies }}{\text { factor income of agricultural incomes }}
$$

The factor income from agricultural activity is the income derived from the factors used in agricultural production (land, labor and capital). It is calculated by subtracting the value of intermediate consumption, consumption of basic capital (depreciation) and the production taxes from the value of the agricultural produce at basic prices, and adding the value of (other) productive sub-funds. In general, it does not include income from other sources (non-agricultural activities, salaries, social benefits, property income, etc.) (5).

- Indicator for measuring the ratio between the payments received and the income of the farmers. This indicator gives an idea for the incomes, based on the Farm Accountancy Data System (FADS), as its latest figures are for 2015 and preliminary data for 2016 .

FADS is a tool for assessing farm incomes in terms of the EU Common Agricultural Policy.
The system is based on the accounting data from a sample of over 80000 farms across all Member States of the EU (4).

The index gives an idea of direct payments as a ratio between farm incomes and the net value added.

Net value added (NVA) is calculated, as depreciation costs are deducted from the gross production produce (7).

For the purposes of this study the net value added is defined as the factor income from agricultural activities.

The indicator for measuring the ratio between the received payments and farmers' incomes can be presented :

$$
\text { DP }=\frac{\text { incomes }}{\text { net value added }} \text {, }
$$

- Evaluation of the support to producers from the Organization for Economic Cooperation and Development (OECD), presenting the ratio of farm support to farmers' incomes. This evaluation also includes support for the agricultural sector (ie general support of services), which is not received by the individual farmers and includes support paid by the consumers in the form of higher prices in the so-called support.

The OECD indicator is a ratio of the value of the total gross income of farms, measured by the value of the total agricultural output (at farm purchase prices), plus the provided budget support. It is calculated as a percentage and gives the so-called producer's evaluation (PSE- Producer Support Estimate). Important is the ratio of gross transfers to farm incomes, and not to agricultural incomes, no matter if they are measured as income from factor or entrepreneurial (family) income.

- The Eurostat indicator is based entirely on the Economic Accounts for Agriculture (EAA). EAAs are satellite accounts of national accounts, which provide additional information and use concepts adapted to the specific nature of the industry. Data on satellite economic accounts is being developed in accordance with Eurostat's core methodology, published in the „Manual on the economic Accounts for Agriculture and Forestry EAA/EAF". Their main purpose is to provide basic information on the development of data on the domestic 
product, and in particular on the contribution of the agriculture sector to the national economy. Secondly, their purpose is to measure the income level of farms and reflect trends in its change over the years. The indicator "Produce by industry "Agriculture"" is a major element of the "Production" account of the satellite economic accounts. It is calculated for a calendar year at basic and producer prices (incl. national and European product subsidies), at current and comparable value (8).

A deeper and more detailed study is possible through interpreting the types of activities in a certain way. This would help to analyze and evaluate changes in the structure of agrarian production, outlining the need to achieve consistency between structural- assortment proposals and their market demand $(9,10)$.

The Eurostat indicator consists of two elements: product subsidies and other subsidies for production. The first ones are subsidies that are directly related to products such as payments bound to production, whereas 'other subsidies on production' refer to any other subsidies paid to non-product farmers (for example, decoupled payments, wage subsidies, interest subsidies, environmental payments, etc.). Unlike the OECD, the Eurostat subsidy figures do not include subsidies for intermediate consumption, which are reflected in buyers' agricultural accounts.
The governments and institutions of the European Union should focus their research programs on the key challenges facing agriculture. Investing in sustainable agriculture would provide the Community with a leading global position consistent with the European agricultural model (12).

\section{ANALYSIS OF INDICATORS FOR MEASURING THE RELATIONSHIP BETWEEN INCOME AND DIRECT PAYMENTS TO FARMERS}

The characteristic of the examined indicators to measure the relationship between income and direct payments to farmers is the basis for their analysis.

- Regarding the indicator for calculating the ratio of direct payments and total subsidies to farm incomes, known as the indicator of the Chief Directorate for Agriculture and Rural Development, the submitted data is not exhaustive. This requires additional information from other sources. For the purpose of this study, it is accepted that the value of the total subsidies corresponds to those identified as "operational subsidies" according to Eurostat data.

The latest update (as of January 7, 2019) This indicator gives an idea for the period of 2011 to 2015 - Figure 1:

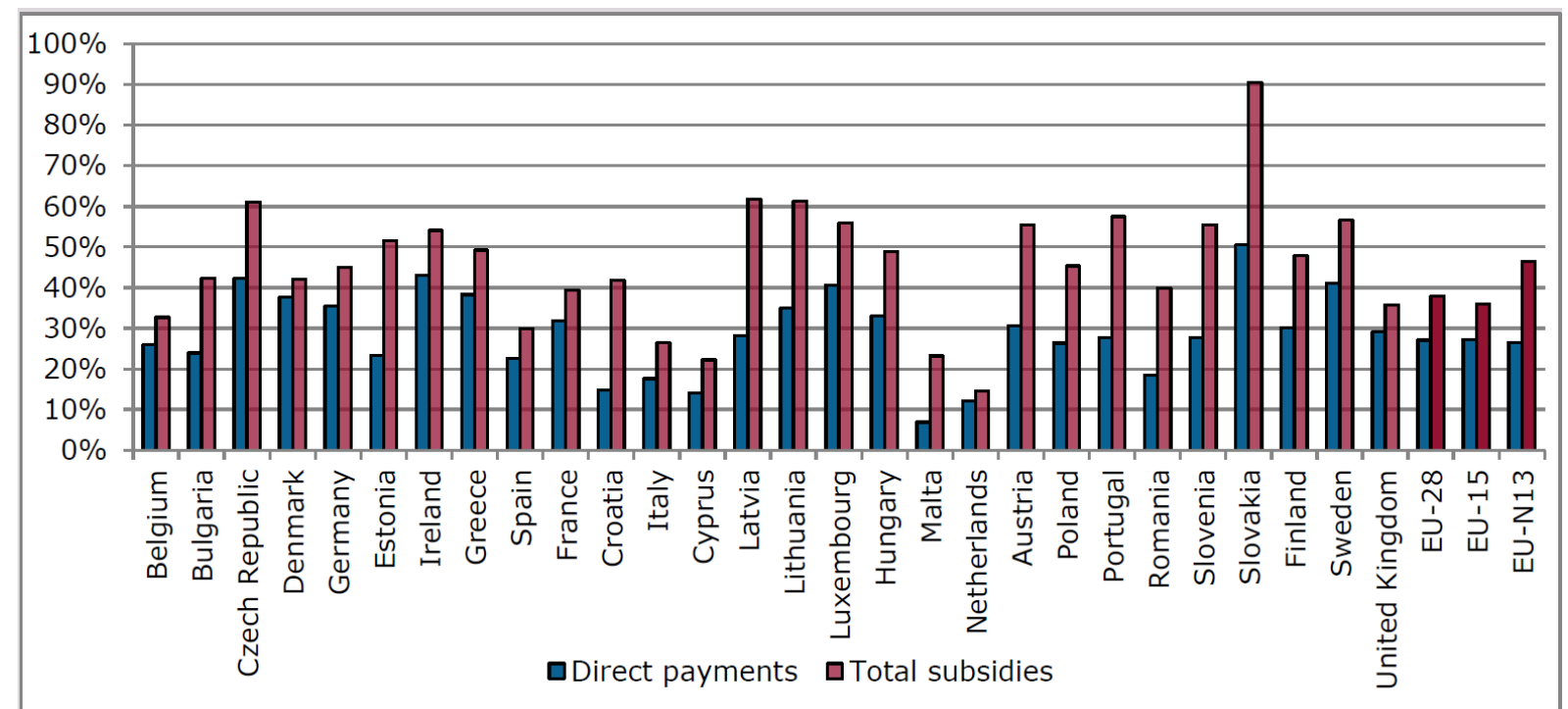

Figure 1. Share of direct payments and subsidies in total factor income from agricultural activities, 2011-2015 Source: DG AGRI

On the basis of the information presented, it is evident that the average share of European direct payments in the factor income from agricultural activities for 2011-2015 is $27 \%$. This "hides" significant differences between Member States ranging up to $15 \%$ in Croatia, 
Cyprus, Malta and the Netherlands and over $40 \%$ in the Czech Republic, Ireland, Luxembourg, Slovakia and Sweden.

Taking into account all subsidies, the amount of the total public support reaches an average of $38 \%$ of the European average agricultural income.

Referring to Figure 1, two disadvantages can be highlighted.

First, it is not sufficiently up to date. As of 7 January 2019, it presents data on the average indicator for the period 2011-2015.

Second, the Directorate-General for Agriculture and Rural Development does not support its indicators as time series.

- The FADN indicator for measuring the ratio between payments received and farmers' incomes is the only source that shows the
TSVETANOV H. dependency on direct payments for different types of farming activities.

Direct payments represent a significant share of net value added (42-50\%) in farms specializing in livestock grazing, mixed crops and arable crops. On the other hand, direct payments have an insignificant role in maintaining income in the wine and horticulture sectors. To deepen the reflection it is possible to derive assessments at NUTS2 regions and farm size.

The share of direct payments by Member States at EU level per farm in 2015 is presented in Figure 2.

FADS represents the ratio of direct payments to factor income in 2015 by Member States. In 2015 , direct payments were an average of $30 \%$ of EU-28 net added value, like in 2014.

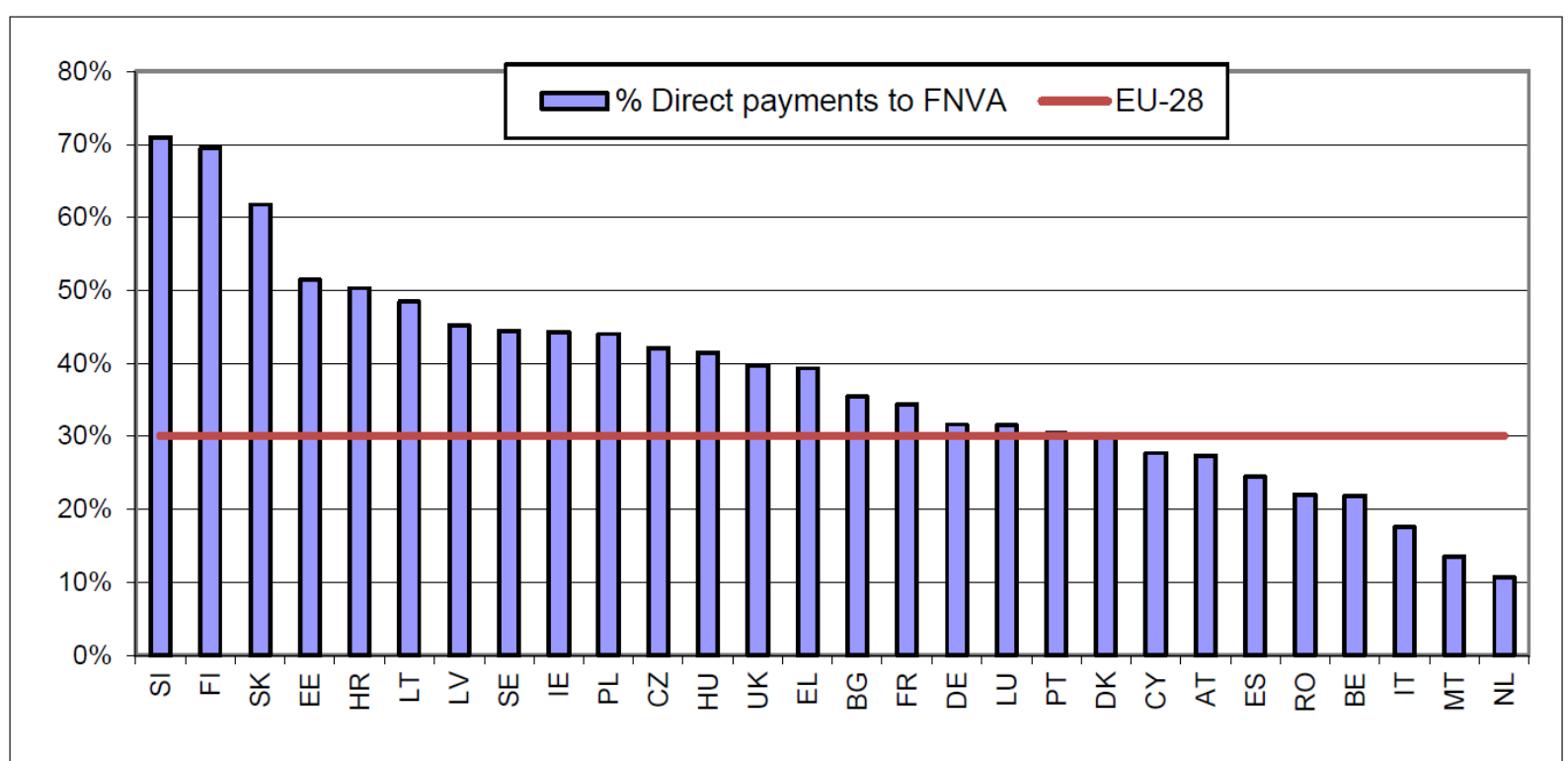

Figure 2. Share of direct payments based on the ratio between farm income and net value added (NVA) farm in Member States in 2015 (average farm at EU level)

Source: Chief Directorate "Agriculture and Rural Development" - FADN

This average does not allow drawing a comparison in parallel with the indicator of the Chief Directorate for Agriculture and Rural Development for direct payments of $27 \%$ for EU-28, as it is an average value, formed over a four years period (2011-2015). Direct payments, expressed as a percentage of net value added, are highest in Slovenia $(71 \%)$, followed by Finland (69\%), Slovakia (62\%) and Estonia (51\%). On the other hand, direct payments in the Netherlands account for only $11 \%$ of the net added value, indicating that the country is primarily focused on less subsidized sectors, such as horticulture and pig and poultry farming - Figure 3.

The figure represents the dependence of the agriculture on direct payments in terms of size, type of activity and operational subsidies by intensity class. The intensity level is measured in terms of intermediate consumption per hectare of utilized agricultural area (UAA). The higher the intensity, the greater the direct payment per hectare. However, the share of direct income payments is higher for largescale classes than for very intensive classes. 


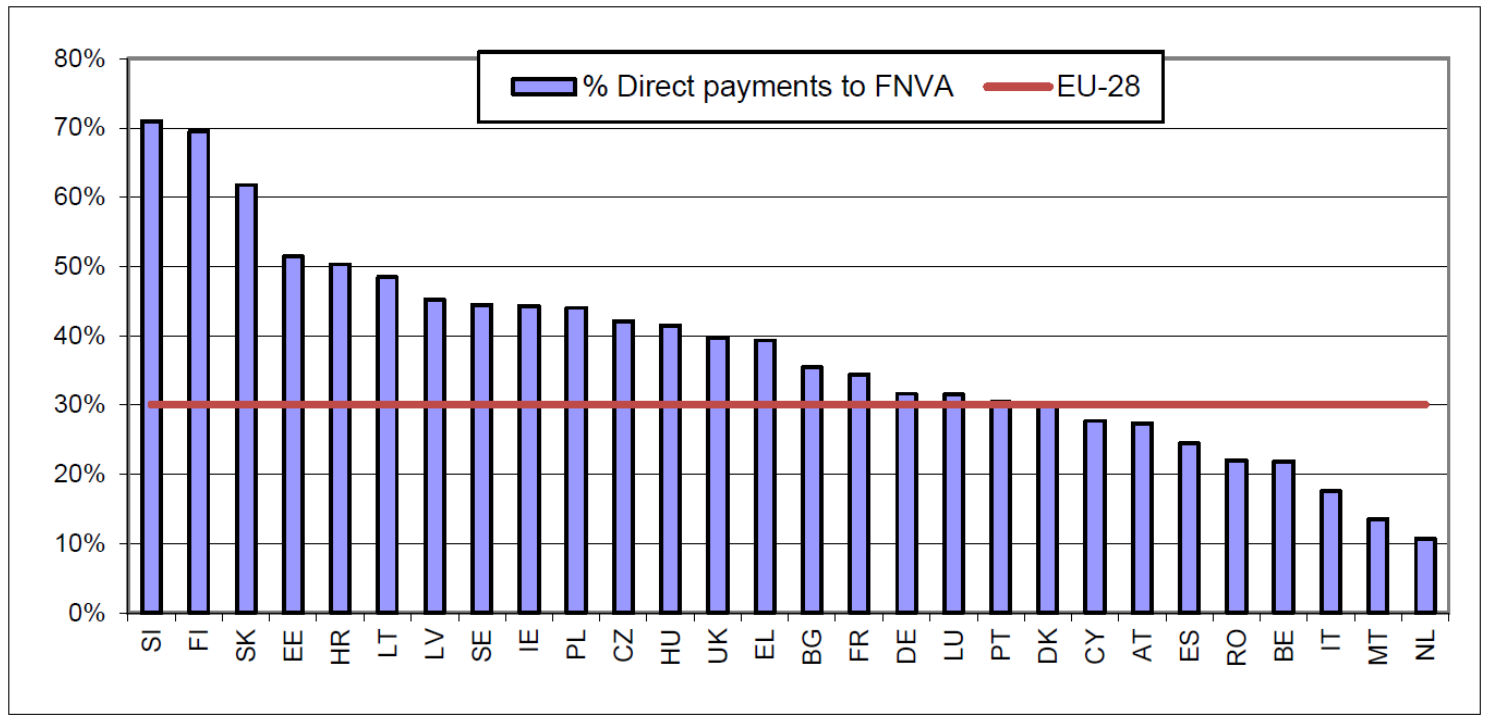

Figure 3. Share of direct payments based on the ratio between the income of farms and net value added (NVA) of farms by type of farming in 2015 (average farm at EU level)

Source: DG AGRI EU-FADN

As disadvantages of the FADS indicator for measuring the ratio of payments received to farmers' incomes, the following can be determined:

- the definition of support included only direct payments, not payments for rural development; - FADS does not support time rows for this indicator;

- FADS is exploring as a priority European farms.
The survey covers about 80,000 farms. They account for about 4.7 million of the 10.3 million holdings at European level.

- insufficient current public data (with preliminary character 2016 ).

The OECD indicator contains time series (this can be done for the FADS indicator using the public database). The benchmark defined as operating subsidies in terms of factor income or entrepreneurial income for the period 20052017 is presented in Figure 4.

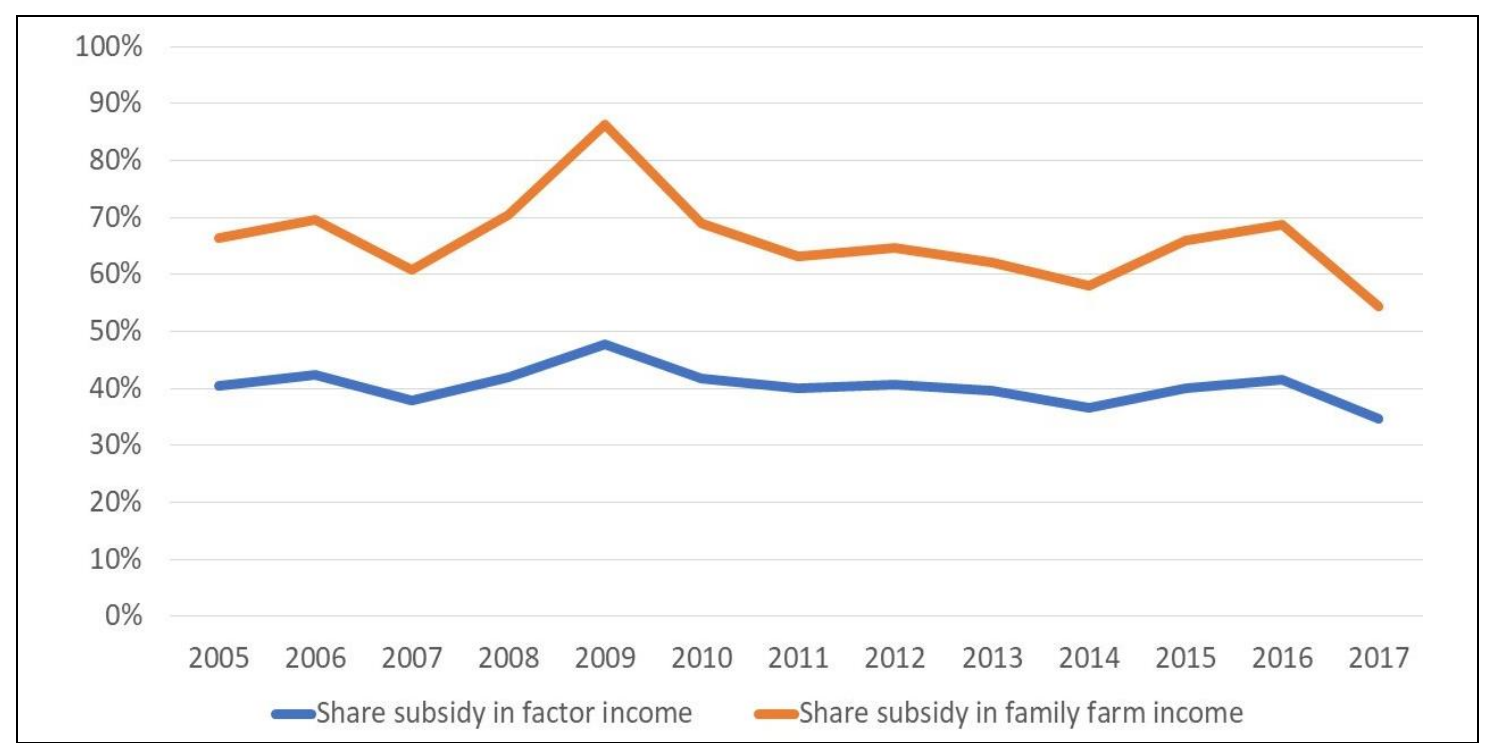

Figure 4. OECD indicator: Share of operating subsidies in farm incomes, the EU-28

Source: Alan Matttwes calculations based on OECD PSE database

http://stats.oecd.org/wbos/fileview2.aspx@IDFile=b19a487e-0c57-4e5d-8d37- 
On average, the operating subsidies make up $40 \%$ of the agricultural factor income and $66 \%$ of the family income of the farms in the period 2005-2017. The 40\% share can be compared with the Chief Directorate Agriculture and Rural Development's indicator for total subsidies compared to the $38 \%$ factor income for 2011-2015, which shows a close correlation. The proportion of dependence on the OECD indicator is $66 \%$ in the family income of farms. This indicator is also close to the FADN indicator.

For factor income, the share of the subsidy has fallen from $42 \%$

2005-2009 to less than 39\% in 2013-2017. Subsidies in family farm incomes fell sharply from $71 \%$ to $62 \%$. The latter trend reflects the steadily rising income of the farmers' family in nominal terms, while operating subsidies remain stable.

As a major disadvantage of the OECD indicator, it can be said that it is only available at the level of the European Community, not the individual Member States. This negative can be avoided by using the Eurostat indicator. Each of these three possibilities for the characterization of payments in respect of the income of farmers has its strengths and weaknesses.

- It is possible to use an indicator, derived from Eurostat (Statistical Office of the
TSVETANOV H.

European Union) to calculate the ratio of payments to farms and farmers' incomes. This indicator is perceived as the latest one for comparisons between Member States of the European Union - Figure 5. The advantages of the indicator, derived from Eurostat (Statistical Office of the European Union) is limited to the following: up-to-date, easily accessible and can be calculated for single Member States. Disadvantage is the impossibility to cover subsidies for mid-production materials.

The Eurostat indicator shows significant similarity to OECD indicator. Its share, depending on the subsidy in family farm income for the period 2005-2017 (not to be taken into account in 2018) is 62\% compared to the OECD indicator of $66 \%$. The share of the subsidy for Factor Income is $38 \%$ compared to the $40 \%$ OECD (this corresponds to the Chief Directorate Agriculture and Rural Development indicator for the total subsidy in factor income for the shorter period 20112015).

The same downward trends are observed. Regarding the share of operating subsidies in factor income, the share reflects a $40 \%$ reduction in 2005-2009 to less than 36\% in 2013-2017. Similar operating income subsidy shares in farm income are 67\%, and, respectively, $57 \%$.

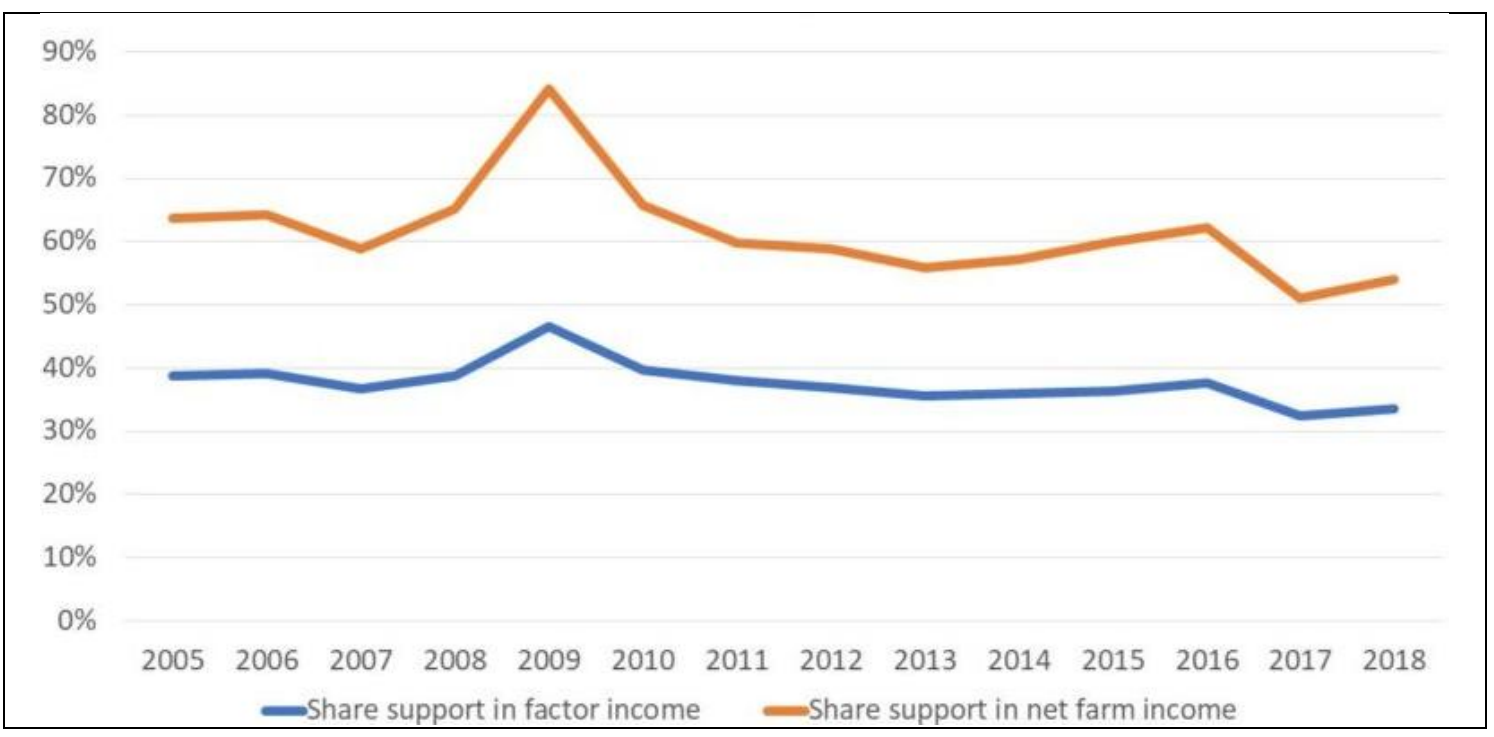

Figure 5. Eurostat Indicator: share of operating subsidies in farm incomes, the EU-28

Source: Alan Matttwes own calculations based on Eurostat, Economic accounts for agriculture at current prices

\section{CONCLUSION}

Based the information presented, it is clear that European producers are heavily dependent on public support in the form of direct payments, rural development and other economic levers. It can be summarized that, despite the difference in definitions of public support, the 
different methodologies are very consistent and with a high degree of consistency between them. Based on the Eurostat indicator, public transfers are currently (average for 2014-2018) about $35 \%$ of agricultural incomes and $57 \%$ of family farm incomes. Based on data over the last decade, there has been a slow decline in farm income dependency on public support.

The publicly available information on income and direct payments to farmers requires maintaining timely and unified database - a grounding for future economic studies.

In conclusion, two recommendations can be determined. The first is that the dependency of farmers' incomes on public support through the Eurostat indicator should become a key indicator of the European Union's Common Agricultural Policy and be taken into account when preparing strategic plans at European level. The public must be aware of the degree of dependence of farm incomes of public support and that should be the starting point when developing plans for the future of the common European agricultural policy to reduce this dependency over time.

This will require further differentiation of the category "Other non-production subsidies" in the economic accounts for agriculture, in terms of the category of payments intended only for transfer payments to support farm incomes and payments intended for the payment of public goods. This distinction will become increasingly important as farm compensation schemes are developed to provide public goods and ecosystem services using public funds. The aim is to be able to measure the extent of these "good" subsidies (second recommendation).

The common feature of the proposed options is that the indicators are used in order to track support for individual farmers.

\section{REFERENCES}

1. European Commission. (2018). EU budget: Commission proposes a modern budget for a Union that protects, empowers and defends. Brussels.

2. Matthews, A. Measuring farmers' dependence on public payments, $\mathrm{http} / / /$ capreform.eu/measuring-farmersdependence-on-public-payments, 08/01/2019.

3. Ministers of agriculture from Finland France - Greece - Ireland - Portugal -
Spain. (2018). Memorandum - Future MFF - CAP.

4. Owen, P. \& other. Basic Payment Scheme for farmers - operationally on track, but limited impact on simplification, targeting and the convergence of aid levels, PDF ISBN 978-92-872-4048-4 ISSN 1977-5679, 2018, p. 7.

5. Kubik, A. \& other. Is the Commission's system for performance measurement in relation to farmers' incomes well designed and based on sound data?, PDF ISBN 97892-872-4048-4, ISSN 1977-5679, 2016, p.

6. Owen, P. \& other. EU support to young farmers should be better targeted to foster effective generational renewal, https://www.eca.europa.eu/

Lists/ECADocuments/SR17_10/SR_YOUN G_FARMERS_EN.pdf, p. 5, 20/05/2019

7. Sistema za zemedelska schetovodna informazia, Rezultati I analizi, 2015, Ministersvo na zemedelieto, hranite I gorite, otdel "Agrostatistika", №336 yanuari 2018, p. 8

8. Ikonomicheski smetki za selskoto stopanstvo, Nacionalen statisticheski institut,

http://www.nsi.bg/bg/content/869/икономи чески -сметки-за-селското-стопанство, 20/05/2019

9. Petrova, S. Obosnovavane strukturiraneto na asortimenta na agrarni produkti. Sbornik dikladi ot Yubileina nauchnoprakticheska konferencia $s$ mejdunarodno uchastie "Nacionalniat agraren sector - element na evropeiskite zemedelski regioni $\mathrm{v}$ strategiata "Evropa 2020", Tom I, AI "Tsenov", Svishtov, p. 267-272, 2014.

10.Petrova, S. Izsledvane na promenite $\mathrm{v}$ strukturata na asortimenta na agrarni produkti. Sbornik dokladi ot Krygla masa "Obshtata selskostopanska politika na Evropeiskia syiuz I agrobiznesa v Republika Bylgaria - ikonomicheski I pravni problemi, AI “Tsenov”, Svishtov, p. 113-118, 2016.

11.Blazheva, V. Proizvodstvo I realizacia na konvencionalna I biologichna selskostopanska produkcia. AI "Tsenov", Svishtov, Biblioteka "Stopanski sviat", ISSN: 1310-2737, 2014, p. 123, c. 23.

12.Blazheva, V. Tehnologichni I ikonomicheski problemi na proizvodstvoto I tyrgoviata $\mathrm{s}$ genetichno modificirani organizmi. AI "Tsenov", Svishtov, ISBN: 978-954-23-0870-6, 2013, p. 138 